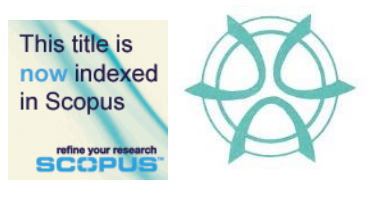

PLANNING MALAYSIA:

Journal of the Malaysian Institute of Planners

VOLUME 15 ISSUE 1 (2017), Page 261 - 270

\title{
THE ESTABLISHMENT OF ISLAMIC DWELLING PRINCIPLES FOR THE MALAYSIAN COMMUNITIES
}

\author{
Wan Norisma Wan Ismail ${ }^{1}$, Fadli Arabi ${ }^{2}$, Elina Mohd Husini ${ }^{3}$, Fatin Nur Sakinah \\ Zolkifly $^{4}$, Zuhairuse Md. Darus ${ }^{5}$, Nor Haslina Abd. Jaafar ${ }^{6}$, \& Azhani Abd Manaf ${ }^{7}$ \\ ${ }_{1,2,3,4,5}$ Department of Architecture \\ UNIVERSITI SAINS ISLAM MALAYSIA \\ ${ }^{6}$ Department of Architecture \\ UNIVERSITI KEBANGSAAN MALAYSIA \\ ${ }^{7}$ Kulliyyah of Architecture \& Environmental Design \\ INTERNATIONAL ISLAMIC UNIVERSITY MALAYSIA
}

\begin{abstract}
Strong family ties built on the teachings of the Quran and Sunnah produce excellent foundation in forming a household which are constantly under the protection and blessing of Allah and in turn contribute to the overall health of a community. A dwelling filled with the remembrance of Allah will no doubt find an aura of peace and tranquillity. This is called a home, a place for a family to worship Allah, to relax body and mind, enjoy legitimate worldly delights, teach, learn and propagate the message of Islam. Therefore, provision and design of a dwelling should be considered important to make it a blessed home. This includes the provision of spaces for religious activities, daily basic chores of households, social production, reproduction hygiene needs, privacy and security. Cultural, religious and sustainable aspects of inhabitants should be considered in the planning and design process of a dwelling in the Malaysian context. The Syariah sources have provided basis for its design to conform to Islamic criteria, thereby facilitating various ibadah activities for the inhabitants and users. A review of theory and philosophy of dwelling from Islamic perspective is analysed to justify the comprehensive living approach as promoted by Islam. This paper aims to review literature pertaining to housing principles in Islam and to present basic principles for developing housing criteria based on Islamic teachings.
\end{abstract}

Keyword: Islamic, dwelling, principles, model, design, communities

Date Received: $30^{\text {th }}$ April 2016

Date of Acceptance: $30^{\text {th }}$ October 2016 
Wan Norisma Wan Ismail, Fadli Arabi, Elina, Fatin Nur Sakinah, Zuhairuse, Nor Haslina, \& Azhani

The Establishment of Islamic Dwelling Principles for The Malaysian Communities

\section{INTRODUCTION}

Dwelling may mean the same as house, home, residence, abide, lodging, accommodation, or housing, among other meanings. The social unit that lives in a dwelling is known as household. Most commonly, a household is a family unit of some kind, though households can be other social group, such as single persons, or groups of unrelated individuals. Many people leave their houses during the day for work and recreation and return home for other activities. The meaning of dwellings has been studied from many different perspectives, such as psychology, phenomenology, sociology and environment-behaviour studies. A good dwelling design must be set out according to the conditions of that locality and meet the technical, hygienic, quality requirements and social-cultural aspects. Coolen (2006) notes that a dwelling is an individual's primary anchor in the environment. It may serve many functions, such as shelter, privacy, security, control and status. From an ecological point of view the meaning of dwellings lies in these functional relationships between human beings and their dwellings.

\section{DWELLING FROM ISLAMIC POINT OF VIEW}

Islam shaped ideas and styles about dwellings and other architectural forms as well. A dwelling was once considered a typology within Islamic architecture, as it facilitated the religious life as it was a space for daily prayer at home. It was designed based on religious prescriptive regarding family, privacy, spirituality and hospitality (Ibrahim, 2012). Yusuf al-Qardhawi, the Islamic researcher and chairman of the International Union of Muslim Scholars, defines a dwelling as the place where an individual protects himself from the climatic elements and in which he finds freedom from the restrictions and pressure of society. It is a place of rest for the body, and relaxation for the mind and soul. The Quran highlights that a dwelling is a shelter or a private sanctuary to its residents. Allah says, "And Allah has made for you from your homes a place of rest..." (al-Nahl 16:80).

Creating an atmosphere of faith in the home and taking the home as a place of worship is very important as Allah says, "And We inspired to Moses and his brother, "Settle your people in Egypt in houses and make your houses [facing the] qiblah and establish prayer and give good tidings to the believers" (Yunus 10:87).

A dwelling from an Islamic view celebrates good and righteous people and seekers of knowledge to visit the home. As Allah says, "My Lord, forgive me and my parents and whoever enters my house a believer and the believing men and believing women..." (Nuh 71:28).

\section{SUMMARY OF LITERATURE REVIEW}

In order to identify publications that provide insights of Islamic dwelling, database searches were undertaken. Thirty selected publications published from 2000 to 2015 were selected for this research. However, only 15 most related 
PLANNING MALAYSIA

Journal of the Malaysia Institute of Planners (2017)

publications were chosen for the purpose of this paper. These publications are looking at as many criteria as possible and their respective principles to the design of Islamic dwellings. A summary of all 15 publications are provided in Table 1 below.

\section{RESEARCH FINDINGS}

\section{Principles of Islamic Dwelling}

Based on the publications analysed and the key findings in Table 1, the following are the main domains which should feature in nearly all Islamic dwellings.

\section{Location - Land}

The most important feature for an Islamic dwelling is its land, good air, much water, and flat and smooth land. Ali (as) stated, 'Housing is not desirable, but with three things: good air, plenty of water and fertile ground' (Amar, Ismail \& Salleh, 2012). Imam Ali (as) also emphasizes on suitable home and states, 'The blessing of a house is its good location, large yard and its neighbours'. Besides that, a dwelling is best located near to a mosque to enable men to join the congregational prayers.

\section{Climate and Topography}

All climatic aspects within the tropical regions such as climate, topography, wind direction, sun movement and humidity must be taken into account for effective self-heating, cooling, ventilation and illuminating mechanism. The adaptation of climate-responsive design in coping with heat and humidity reflected in dwelling design of a vernacular Malay house such as open floor plan arrangement, raised floor on stilt, full length window, large overhang, interconnected open space, and shading trees and shrubs helps modify microclimate around the house by cooling down air temperature and directing cool breeze towards the dwelling (Limthongsakul et al., 2012). Generally, an Islamic house will be favourably responsive to its ecosystem, energy efficient, nature friendly and sustainable where it will not depend solely on artificial sources and means of energy (Omer, 2010).

\section{Orientation - Qiblah Direction}

Qiblah means the direction one should face when observing the prayer. Therefore, the orientation of every Islamic dwelling should consider qiblah direction. The Sunnah of the Prophet (peace be upon him) is to respect and revere the prayer direction. This is indicated in several hadiths, such as "When one of you stands in his prayer, he is in close conversation with his Lord or his Lord is between him and his qiblah. Therefore no one should spit in the direction of his qiblah" [Sahih Bukhari, Kitab al-Salah]. 
Wan Norisma Wan Ismail, Fadli Arabi, Elina, Fatin Nur Sakinah, Zuhairuse, Nor Haslina, \& Azhani The Establishment of Islamic Dwelling Principles for The Malaysian Communities

Table 1 Summary of Literature on Islamic Housing Principles

\begin{tabular}{|c|c|c|c|c|c|}
\hline No & Author(s) & Year & Publication & Purpose & Key findings \\
\hline 1 & $\begin{array}{l}\text { Fakriah and } \\
\text { Ahmad }\end{array}$ & 2009 & $\begin{array}{l}\text { Journal } \\
\text { article }\end{array}$ & $\begin{array}{l}\text { To assess the } \\
\text { adaptable house } \\
\text { design attributes in } \\
\text { Malaysia related to } \\
\text { Islamic principles. }\end{array}$ & $\begin{array}{l}\text { Space organization (sleeping area, } \\
\text { eating area, recreation and leisure area, } \\
\text { kitchen, toilets, storage and circulation } \\
\text { areas) and architectural design style } \\
\text { are the main determining factors of an } \\
\text { Islamic house design. }\end{array}$ \\
\hline 2 & $\begin{array}{l}\text { Majid } \\
\text { Yazdani } \\
\text { et al. }\end{array}$ & 2013 & $\begin{array}{l}\text { Journal } \\
\text { article }\end{array}$ & $\begin{array}{l}\text { To analyse the } \\
\text { characteristics of } \\
\text { suitable home from } \\
\text { Islamic views and } \\
\text { modern architecture }\end{array}$ & $\begin{array}{l}\text { Important housing characteristics in } \\
\text { Islam view are suitable land, location, } \\
\text { neighbour, building design and its } \\
\text { architecture and extension of the } \\
\text { home. }\end{array}$ \\
\hline 3 & $\begin{array}{l}\text { Hashim } \\
\text { et al. }\end{array}$ & 2008 & $\begin{array}{l}\text { Journal } \\
\text { article }\end{array}$ & $\begin{array}{l}\text { To identify urban } \\
\text { malays user-behavior } \\
\text { and perspective on } \\
\text { privacy and spatial } \\
\text { organization r of } \\
\text { housing }\end{array}$ & $\begin{array}{l}\text { Re-introduction of the serambi } \\
\text { concept in modern housing as a } \\
\text { transition zone for informal } \\
\text { entertaining and social interaction } \\
\text { space for the immediate } \\
\text { neighbourhood to fulfill privacy needs. }\end{array}$ \\
\hline 4 & $\begin{array}{l}\text { Ahmad and } \\
\text { Zaiton }\end{array}$ & 2008 & $\begin{array}{l}\text { Journal } \\
\text { article }\end{array}$ & $\begin{array}{l}\text { To study the influence } \\
\text { of privacy regulation } \\
\text { on urban malay } \\
\text { families living in } \\
\text { terrace housing. }\end{array}$ & $\begin{array}{l}\text { Defined territory and the need to } \\
\text { respect the neighbors' privacy are } \\
\text { found to indirectly affect community } \\
\text { intimacy among Muslim families } \\
\text { living in terrace housings. }\end{array}$ \\
\hline 5 & $\begin{array}{l}\text { Ahmad et } \\
\text { al. }\end{array}$ & 2005 & $\begin{array}{l}\text { Journal } \\
\text { article }\end{array}$ & $\begin{array}{l}\text { To analyse visual } \\
\text { privacy and family } \\
\text { intimacy among } \\
\text { Malay inhabitants } \\
\text { living in low-cost } \\
\text { terrace housing. }\end{array}$ & $\begin{array}{l}\text { Visual privacy due to location of } \\
\text { openings, separation of sleeping places } \\
\text { of male and female family members } \\
\text { and separation area during social } \\
\text { interactions should be considered in } \\
\text { the planning and design process. }\end{array}$ \\
\hline 6 & $\begin{array}{l}\text { Hannah } \\
\text { Ibrahim }\end{array}$ & 2012 & $\begin{array}{c}\text { Doctoral } \\
\text { Dissertation }\end{array}$ & $\begin{array}{l}\text { To identify a } \\
\text { contemporary house } \\
\text { that is a manifestation } \\
\text { of the practices of the } \\
\text { Islamic religion. }\end{array}$ & $\begin{array}{l}\text { Courtyard type dwelling, openings on } \\
\text { external walls, bent entry, separation } \\
\text { of male and female area, clear division } \\
\text { of public, private and semiprivate } \\
\text { areas, multifunction musallah design } \\
\text { for individual and collective. }\end{array}$ \\
\hline 7 & S. Omer & 2010 & Book & $\begin{array}{l}\text { To analyse the subject } \\
\text { of housing in Islam, as } \\
\text { both in concept and } \\
\text { reality. }\end{array}$ & $\begin{array}{l}\text { Front door design, windows design } \\
\text { and other apertures, privacy protection } \\
\text { among family members / between } \\
\text { visitors and the occupants, maid's } \\
\text { room, bedrooms, toilets, kitchen, } \\
\text { house orientation consider qiblah } \\
\text { direction, musolla and studying area. }\end{array}$ \\
\hline 8 & S. Omer & 2011 & Article & $\begin{array}{l}\text { To identify Islamic } \\
\text { principles through } \\
\text { conceptualizing } \\
\text { Islamic housing }\end{array}$ & $\begin{array}{l}\text { Inner courtyard, partly or fully } \\
\text { screened windows, raising windows } \\
\text { above the eye level, bent entrances, } \\
\text { parapets, or protective walls, along the } \\
\text { edges of balconies and open roofs, } \\
\text { double circulation houses. }\end{array}$ \\
\hline 9 & $\begin{array}{l}\text { Fakriah and } \\
\text { Ahmad }\end{array}$ & 2009 & $\begin{array}{l}\text { Journal } \\
\text { article }\end{array}$ & $\begin{array}{l}\text { To assess the } \\
\text { adaptable house } \\
\text { design attributes in } \\
\text { Malaysia that relate to } \\
\text { Islamic principles. }\end{array}$ & $\begin{array}{l}\text { Space organization (sleeping area, } \\
\text { eating area, recreation and leisure area, } \\
\text { kitchen, toilets, storage and circulation } \\
\text { areas) and architectural design style } \\
\text { are the main determining factors of an } \\
\text { Islamic house design. }\end{array}$ \\
\hline
\end{tabular}




\begin{tabular}{|c|c|c|c|c|c|}
\hline 10 & $\begin{array}{l}\text { Nahid and } \\
\text { Sakineh }\end{array}$ & 2001 & $\begin{array}{c}\text { Journal } \\
\text { article }\end{array}$ & $\begin{array}{l}\text { To investigate muslim } \\
\text { women } \\
\text { requirements } \\
\begin{array}{l}\text { ventilation } \\
\text { Malaysian }\end{array} \\
\begin{array}{l}\text { needs in } \\
\text { houses }\end{array}\end{array}$ & $\begin{array}{l}\text { Privacy spaces in a house can be } \\
\text { divided into public area, semi-private } \\
\text { and private. Terrace houses could not } \\
\text { provide complete privacy and some } \\
\text { traditional adaptation can be applied } \\
\text { by rearrange the unit floor. }\end{array}$ \\
\hline 11 & $\begin{array}{l}\text { Ghaffarian } \\
\text { Hoseini } \\
\text { et al. }\end{array}$ & 2014 & $\begin{array}{c}\text { Journal } \\
\text { article }\end{array}$ & $\begin{array}{l}\text { To analyse the } \\
\text { environmental and } \\
\text { social-culture values } \\
\text { of Malays vernacular } \\
\text { house. }\end{array}$ & $\begin{array}{l}\text { Nature and tropical climate are main } \\
\text { basis of design. Privacy and optimal } \\
\text { use of space are significant social } \\
\text { values while natural ventilation is } \\
\text { most significant environmental value. }\end{array}$ \\
\hline 12 & $\begin{array}{l}\text { Muhammad } \\
\text { Suhaimi bin } \\
\text { Musa }\end{array}$ & 2011 & $\begin{array}{c}\text { Journal } \\
\text { article }\end{array}$ & $\begin{array}{l}\text { To discuss topics on } \\
\text { the needs of design } \\
\text { elements for the } \\
\text { establishment of } \\
\text { Muslim behaviour in } \\
\text { traditional and modern } \\
\text { Muslim dwelling. }\end{array}$ & $\begin{array}{l}\text { Space configuration that consider } \\
\text { place of worship, size of space, } \\
\text { internal layout, privacy, cleanliness, } \\
\text { pictures and study of traditional Malay } \\
\text { house in space zoning. }\end{array}$ \\
\hline 13 & $\begin{array}{l}\text { Noorul } \\
\text { Huda }\end{array}$ & 2013 & $\begin{array}{c}\text { Journal } \\
\text { article }\end{array}$ & $\begin{array}{l}\text { To identify residential } \\
\text { visual privacy on } \\
\text { traditional and modern } \\
\text { architecture house } \\
\text { designs and urban } \\
\text { designs }\end{array}$ & $\begin{array}{l}\text { Majority of women regard visual } \\
\text { privacy at home from outsider as } \\
\text { extremely important. Urban designers } \\
\text { are to incorporate core values of the } \\
\text { culture to meet the needs of residents. }\end{array}$ \\
\hline 14 & $\begin{array}{l}\text { Zeenat } \\
\text { Begam }\end{array}$ & 2011 & $\begin{array}{c}\text { Journal } \\
\text { article }\end{array}$ & $\begin{array}{l}\text { To find guiding } \\
\text { principle from Al- } \\
\text { Quran and Sunnah } \\
\text { regarding the planning } \\
\text { amd design of a } \\
\text { house. }\end{array}$ & $\begin{array}{l}\text { Privacy is principles that separate } \\
\text { owners private life and public } \\
\text { intercourse which consider visual } \\
\text { privacy and acoustical privacy, safety, } \\
\text { interior decoration aspects, } \\
\text { cleanliness, avoid wastage. }\end{array}$ \\
\hline 15 & Amar et al. & 2012 & $\begin{array}{l}\text { Journal } \\
\text { Article }\end{array}$ & $\begin{array}{l}\text { To produce basic } \\
\text { Islamic guidelines for } \\
\text { the developers to build } \\
\text { and design the internal } \\
\text { part of houses for } \\
\text { Muslims. }\end{array}$ & $\begin{array}{l}\text { A basic guideline of building a } \\
\text { Muslim house accordingly to the } \\
\text { Islamic teachings, considered of house } \\
\text { location and site layout, main } \\
\text { entrance, living and dining area, } \\
\text { fencing and bedrooms. }\end{array}$ \\
\hline
\end{tabular}

\section{Space Configuration (Zoning)}

The spatial planning and layout in the dwelling design should divide spaces that are public, semi-public, semi-private and private spaces. These spaces are determined based on gender segregation, limitation of awrah, privacy and isolation from the interest of the public that constitutes with visual and accessibility restriction. The public spaces receive and entertain non-mahram guests such as neighbours, relatives and friends (Mortada, 2003). The private area is specially created for family members and females without being interfere by non-mahram guests (Mortada, 2003; Abdul Rahim, 2008). Spaces that are indefinite and unclear whether they are public or private allow less control on social interaction and create conflicts (Ramezani \& Hamidi, 2010).

\section{Privacy - Visual Privacy}

Privacy of the dwelling is significantly stated in many places in the Quran. Allah says, "O you, who have believed, do not enter houses other than your own houses 
Wan Norisma Wan Ismail, Fadli Arabi, Elina, Fatin Nur Sakinah, Zuhairuse, Nor Haslina, \& Azhani

The Establishment of Islamic Dwelling Principles for The Malaysian Communities

until you ascertain welcome and greet their inhabitants. That is best for you; perhaps you will be reminded" (An-Nur 24:27).

Visual privacy inside the house should be maintained by the design treatment by both public and private domains as well as spaces declared as sacred such as bedrooms, in the private domain. Guest room location should be close to the entrance and separated from the family domain to maintain the privacy of women in the rest of the house. Creating a space for hosting guests is encouraged in the Muslim dwelling. Although Islam greatly encourages invitation of guests, it disallows mixing between unrelated male guests and the family females. Therefore, direct visual access between the guest domain and family is prohibited. Design measures should be provided to eliminate such access and to maintain the privacy of the family domain. The Quran stated very clearly that one's privacy is one's own right and no one should intervene in it without one's permission. Muslim scholars emphasize three elements of design that can control the visual privacy of a dwelling for instance the entrance door, windows, openings and screen height (Omer, 2010; Mortada, 2003; Abdul Rahim, 2008).

\section{Privacy - Acoustical Privacy}

Acoustical privacy is of no less importance than the visual. Mortada (2003) and Abdul Rahim (2008) mention that privacy of acoustic means controlling the transmission of sound from inside to the outside of the dwelling that can be heard by opening doors and windows. Therefore, precautions should be taken to prevent sound transmission from the house to the outside and from the family domain to the guest inside the house. Through creative space organization and suitable building materials, it ensures the acoustic privacy between the internal zones and the outside zone.

\section{Privacy - Sense of Smell}

Olfactory privacy also plays an important role in the control of smells privacy or odours produced in kitchens to prevent them from spreading to spaces where guests are entertained. Muslim narrated, "If you cook something with gravy, increase the gravy and send some of it to your neighbours." In another hadith, Islam encourages another caring attitudes amongst Muslims as follows, "One is not a perfect Muslims who eats until he is full and leaves his neighbours (also kith and kin, one has more responsibility for them) hungry." [al-Tabarani]

\section{Internal Layout - Main Entrance}

A front door should be designed in such a way that it does not give immediate access to domestic dwelling, but lead to an intermediate space, or a lobby which act as a mediator between inside and outside of the dwelling. In short, it is a buffer between public and personal space (Amlashi, Mousavi \& Falakian, 2013). The buffer can be in the form of a wall or just a screen, outside or right in front of the 
doorway. Ibrahim (2012) notes that the entrance is designed to obstruct any view of the interior: a bent entrance faces a blank wall with reception adjacent. This provides privacy and further protects the house from noise.

\section{Internal Layout - Living \& Dining}

The living area is the most public of the private. It is a place for family and close friends (Omer, 2010). The family area should have an open space allowing for numerous activities at once. It is a space for more intimate family friends to socialize. Thus a living area should be located near a front door. Dining area is a semi-public area. In Islam, it is advisable to have separate doorways for the living, dining and kitchen due to the restriction access of male to the female guests. Having a double circulation system inside the house is recommended.

\section{Internal Layout - Bedroom}

Bedrooms should be designed such that the bed position can be placed perpendicular to the qiblah direction. The bed should be positioned so that someone sleeping on their right side will be facing the qiblah, as recommended by the Prophet (pbuh). One can also sleep with his head facing the qiblah and his feet facing the opposite direction. If one has a study area, one could also orient the desk such that one is facing the qiblah when studying. The Prophet said: "Lie on your right side" (Al-Bukhari \& Muslim). Barra bin "Azib reported, "Messengger of Allah said: If you want to sleep in bed, purify for prayer. Then lie down with you lying on your right side" (AlBukhari).

\section{Internal Layout - Prayer Room}

A main sign of a home that is filled with Allah's remembrance is for it to become lively at tahajjud, fajar and other prayers. Therefore, if one is having a dedicated prayer room, all seating arrangements and prayer rugs should be oriented toward the qiblah. This will ensure that people are facing the qiblah not only while they are praying, but also while they are sitting for dhikr, dua or Qur'an recitation.

\section{Internal Layout - Kitchen}

Kitchens are best located in the deepest and most secured from the public zone of the dwelling since women spend much of their time there. A buffer is needed between the kitchen and other public sections linked between them to ensure that regardless who was in the house, women will not be interrupted of their domestic duties and they are freely to move around.

\section{Internal Layout - Toilet, Bathrooms \& Ablution Area}

Water closet in a toilet should not face the qiblah direction, nor to turn their backs to it. It should be perpendicular to the qiblah direction. This way, one is neither facing the qiblah nor turning one's back on it while relieving oneself. Muslim 
Wan Norisma Wan Ismail, Fadli Arabi, Elina, Fatin Nur Sakinah, Zuhairuse, Nor Haslina, \& Azhani

The Establishment of Islamic Dwelling Principles for The Malaysian Communities

narrated "If you go to defecate, do not face to qiblah nor turn your back towards it. Instead you should turn to your left side or your right". "When any of you goes to relieve himself, he should not face the qiblah nor turn his back on it. He should face the east or west." [Sahih Bukhari, Kitab al-Wudu]. Water hose or hand bidet should be fixed on the right side of the water closet so that one can turn on the tap using the right hands and doing the cleaning by using the left hands. In Islam, it is sunnah to wash one's private parts with water as purification (Amar, Ismail $\&$ Salleh, 2012) The recycled water (Mustakmal) is fine for cleaning but not permissible for ablution. Ablution need pure water (Mutlak) (Amar, Ismail \& Salleh, 2012). Hence, it is good to have a separate compartments for bath, water closet and ablution. Ablution area should be positioned such that one is directly facing the qiblah when doing wudhu.

\section{Internal Decorations}

Traditional Islamic teachings recommend that a Muslim home dweller should beautify the internal space of his/her home by using non idolatry decorations or artefacts, such as flowers and decorated fabrics instead of expensive gold or any animal or human like statues (Mortada, 2003). They are encouraged to decorate their homes with flowers or greenery, pictures and photographs of natural environment because it praises Allah with His beautiful creation.

\section{Openings}

Windows are function to gain natural light, fresh air, view the environment and their neighbourhood. At the same time, it should be designed to comply with the requirements of privacy protection. Placement of the window cannot be in a position parallel to the window of the neighbouring house or neighbouring house entrance. At certain location, windows must be built above the eye level for the upper and lower floor of the dwelling, to maintain the internal privacy (Mortada, 2003; Abdul Rahim, 2008). These openings can be strategically and artistically screened using opaque or semi-transparent glass, parapets, vent blocks, louvres, decorative ornamentations, masyarabiyah, slabs and many more so that the awrah and privacy of the family members are not infringed upon.

\section{Safety}

Having the highest safety and security standards is one of the main criteria of an Islamic dwelling. Yusof (2011) notes that a building with backdoor is necessary because it can be a second exit of the buildings that it is important during emergency. According to her, architects need to comply with Allah's injunctions to achieve the strength of buildings.

\section{Social Interaction - Neighbourhood}

Neighbours are the important subject in buying land or house. Imam Ali (as) states, "Before way ask about about friend of way about friend of way, and before 
buying a house a house ask about neighbours". Prophet (pbuh) says, "Four things are signs of bliss and happiness of man: good spouse, big house, good neighbour and good vehicle". An open space within or outside the dwelling act as a place for socialization and occasions to enhance the spirit of brotherhood. Referring to Hashim and Rahim (2008), sharing of external spaces encourages interaction among the communities and strengthens the community bond.

\section{Internal Recreational}

Dwelling design with an internal opening such as courtyard, terraces or backyards with appropriate recreational facilities or through creative design inventions helps to improve the occupants' physical, mental and spiritual wellbeing. According to Omer (2010), pursuing a good and ingenious recreation at home is indispensable for maintaining one's emotional and psychological wellbeing. This will also enhance the relationship between all family members and as a result eliminate many social illnesses.

\section{Nature Responsive}

It is believed that viewing and being in nature improves our health, both mentally and physically. Weather, nature and temperature clearly influence human behaviour. Thus, an ideal Islamic dwelling will incorporate as much nature as possible and connect open spaces into its fold. Natural ventilation is the most significant environmental value extracted from the analysis of Malay houses (GhaffarianHoseini, Berardi \& Dahlan, 2014). This consideration helps dwellings to be energy efficient, sustainable and eco-friendly.

\section{Disabled Friendly}

An Islamic dwelling should also consider the needs of the disabled and elderly people. The concept of an ideal dwelling has changed over last century as a response to the changing of demographic, health condition and family patterns. Among the considerations for a disabled friendly dwellings are to avoid split levels within the house, clear doorway opening for wheelchair clearance, spacious bedroom for wheelchair turning and window sill between 450 to 600 $\mathrm{mm}$ above floor level to allow view outwards from seated position.

\section{CONCLUSION}

Many research findings indicate that despite significant differences between traditional and modern dwelling design and settings, the majority of its occupants regard visual privacy at home from outsiders as extremely important. Occupants who live in the modern neighbourhood often modify the original design of their homes in order to increase the level of privacy and other aspects. This study concludes that urban designers need to understand and incorporate core values of the culture in which they are working, in order to meet the needs of a city's 
Wan Norisma Wan Ismail, Fadli Arabi, Elina, Fatin Nur Sakinah, Zuhairuse, Nor Haslina, \& Azhani

The Establishment of Islamic Dwelling Principles for The Malaysian Communities

residents. The most appropriate dwelling design fits the use; it is not the use fits design. As Islam requires homes are to be built in accordance with these principles and therefore designers should treat these principles as guidelines of their dwelling design. It is clear here that the design of a Muslim dwelling should be the product of the Islamic beliefs and values of the inhabitants. In conclusion, an Islamic dwelling is Islam manifested.

\section{ACKNOWLEDGEMENTS}

This work was supported in part by USIM under Grant Nos. PPP/USG0115/FST/30/11915.

\section{REFERENCES}

Abdul Rahim, A. (2008). Housing from the Islamic Perspective. Kuala Lumpur. IIUM Press.

Amar, N. Z. M., Ismail, Z., \& Salleh, H. (2012, April). (2012). Guidelines for internal arrangement of Islamic house. Business Engineering and Industrial Applications Colloquium (BEIAC), 2012 IEEE, IEEE, p. 189-194.

Amlashi, A. P., Mousavi, S. Y., \& Falakian, A. (2013). The characteristics of suitable home from Islam point of view in comparison with modern architecture. International Research Journal of Applied and Basic Sciences, 4(5), 1312-1318.

Coolen, H. (2006). The meaning of dwellings: An ecological perspective. Housing, Theory and Society, 23(4), 185-201.

Ghaffarian Hoseini, A., Berardi, U., \& Dahlan, N. D. (2014). What can we learn from Malay vernacular houses? Sustainable Cities and Society, 13, 157-170

Hashim, A. H., \& Rahim, Z. A. (2008). The influence of privacy regulation on urban Malay families living in terrace housing. Archnet-IJAR, 2(2), 94-102.

Ibrahim, H. (2012). The Contemporary Islamic House (Doctoral dissertation). University of Arkansas.

Limthongsakul, S., Vudipong Davivongs, M. L., Santisan, A., Yamyolngam, P., \& Chaisawataree, T. (2012). Sustainable design and Muslim vernacular houses: understanding local wisdom, cultural relationships, and architectural evolution. Kasetsart Journal Soc. Sci, 26, 27-35.

Mortada, H. (2003). Traditional Islamic principles of built environment. London: RoutledgeCurzon.

Omer, S. (2006). Towards an understanding of the concept of the Islamic house. Housing and Building National Research Center Journal, 2(2).

Omer, S. (2010). Islam \& housing. A.S. Noordeen.

Ramezani, S., \& Hamidi, S. (2010). Privacy and social interaction in traditional towns to contemporary urban design in Iran. American Journal of Engineering and Applied Sciences, 3(3), 501-508.

Yusof, Z. B. (2011). Islamic guiding principle (shari'ah law) for architectural interpretation of housing. In M. Rashid (Ed.), Islam and built environment (First edition) (pp. 19-33). Kuala Lumpur: IIUM Press. 